DOI https://doi.org/10.18551/rjoas.2018-12.21

\title{
WOMEN'S ROLE POLICY IN DEVELOPING THE FAMILY ECONOMICS
}

\author{
Suraji \\ Lecturer, University of Hang Tuah, Surabaya, Indonesia \& PhD Student, Ghazali Shafie \\ Graduate School of Government, University of Utara Malaysia, Malaysia \\ E-mail: surajimunawir@gmail.com
}

\begin{abstract}
This research aims to describe, analyze and evaluate in depth of the women's role in the economic development in helping a family's income and economic development both in the village and urban levels. This research uses a case study approach as the qualitative method by interviewing 20 families in Mungkid Village, Mungkid Subdistrict, Magelang Regency, Central Java, Indonesia. This study finds that the economic development by women in Mungkid Village can give short-term and long- term solutions. Women's role in business development also motivates the family in the long-term. Thus, it can be seen from several things in economic development: First, it can motivate the family and the surrounding environment. Second, it can fulfill the educational needs. Third, it can fulfill the household needs including home improvement. Fourth, it can be seen as one of the forms of new change in gender equality as a form of mutual justice. The role of women in economic development needs to be regulated in law to guarantee incentives and employment. The law that regulates the existence of female workers should also regulate the received salary which is based on the regional's minimum standard of wage. Theoretically, it is expected that this research can strengthen the theory of women's role in the development, the strength of family's economy. On the other hand, the government role is expected to regulate and manage women labor as the effort to develop the family's economy as well as paying more attention in the laws specializing in women labor and the regulations to implement it.
\end{abstract}

\section{KEY WORDS}

Policy, women labor, family's economy, public service.

Many groups are paying a lot of attention to workforce issue, either in male and female labors. An improving education level among women in the latest century has changed them in the developing county. However, this condition has not had a significant impact in Indonesia. Although there are few groups in urban and rural areas who are getting more selfconfidence and even capable of adjusting themselves with men in agriculture, mining, manufacturing, energy, trade, transportation, public services working fields. But the viscous dominance of men in Indonesia, especially by questioning the gender barrier, women's roles is seen as a complementary in economic development.

Seriously discussing the women's role in the economic fields and sectors requires a long time and it will not be easily done. Especially, when the discussion about women extends to various fields in our daily life, both in the present and the future. The increasing role of women has been proven by the higher rate of women labor from year to year. If we look at development from 1990 the new working force of working women was $34.4 \%$ which has increased to $67.6 \%$ in 2017 (Siswanto, 2017: 31) in the future, it is expected that increasing social acceptance of working women will increase the women's role in the economy.

On the other hand, it depends on the readiness of the women in facing the competition for jobs by improving their resources quality in accordance with the job sectors which are also in line with their nature and strength as women.

By looking at various external constraints, there is still discrimination or inequality between the distributions of female workers in the type of job. This measurement is very important even when there is no impact on the jobs market. However, it can be clearly seen during the final determination or during the execution of its task in real condition. It is caused 
by the inherent thinking of Indonesian about women in the family environment. It is very important to evaluate working women by reviewing the productivity of working women in economic activities. This is important to do so that women can get an objective assessment by eliminating classical aspects expected by the community and economic actors can fairly evaluate women's role in the economic sectors.

Generally, it has been acknowledged that women's role in economic development is very high. In which they are able to help the family income and the economic development in the village up to urban levels. One of the policies sought by the Local Government up to Village Government is to improve women's role which is not only as the housewife but also a productive worker and become the new investment of economy sources in the family.

Mungkid Village, Mungkid Subdistrict, Magelang Regency, Central Java, Indonesia, is one of the villages that try to encourage its community to improve the economic development. One of the women's roles in the economic development in Mungkid Village is the huge number of women working in the agricultural, services, and unskilled laborers sectors. Although these types of work are considered to be inappropriate, many women in Mungkid Village are very motivated to do it. According to Monograph data of 2017 of Mungkid Village, nearly 60 percent of women work in those sectors.

In general, what is done by the women in Mungkid Village, Magelang Regency, Central Java has disturbed the family members. However, they still have to do it with motivation and the basic needs that they have to fulfill. In terms of economy, it has helped the family needs a lot both in terms of education or unpredictable family needs in the future. Hence, the working women in Mungkid Village, Magelang Regency Central Java can visibly improve the economy and develop the Mungkid Village, Magelang Regency Central Java as the new source of the economy.

\section{LITERATURE REVIEW}

Often in the everyday experiences or in the research activities, when we approach a mother carrying her baby while cleaning the house or washing clothes and ask whether she works, she will say that she is not working or "unemployed". Similarly, when we see a woman sitting around in her house courtyard weaving mat to be handed over to peddlers during the weekend and we ask her neighbor or even the head of RT whether the woman works or not, the answer will be "unemployed" or simply "occupying free time", or doing "side job".

The definition of work is often not only related to what someone does but also the background of the work, and the social opinion given to the job itself (Moore, 1988:43). In our today community, there has been much commercialization with the market orientation which often has a tight differentiation between wage labors or work that generates non-wage income and work or non-income-generating work. Wage labor is considered as productive work, while non-wage work is considered as unproductive. This kind of view is actually inseparable from the two kinds of cultural biases in our society. First, the idea that money is the measurement of value/meaning of an activity. Second, the tendency to make a sharp dichotomy about all the existing symptoms.

In reality, there is a difference between women and men regarding the issue of women's employment opportunities, especially in terms of obtaining education and training as well as improving career in the field of work. This can arise due to stereotypes in the community regarding the women's role. Some psychologists indicate that there are some obstacles for women to be more successful, namely external and internal barriers. External barrier arises because of the influence of feminism. Hence, the type of work that should be carried out is a manifestation of the stereotype of women. The external barrier can also arise due to the discrimination and lack of government funding in providing education, where women are usually the last choice in getting an education. Meanwhile, the internal barrier is caused by Horner effect, Cinderella complex, and low academic confidence. Horner effect is a condition where women having fear of success syndrome when facing a competition with men. It can cause women to achieve far below their real capability. While the Cinderella complex is the nature of dependence on protection and care (Tjiptoherijanto 1996: 124-125). 
Basically, the number of wages in the market will vary in various positions, even with the same human capital. This wage difference will reach the optimum level (in terms of economic well-being) provided that everyone has the same opportunity in achieving his or her expert position as an or as an expert. In terms of assumption, it can be said that business actor perceives workers to have the same expertise as a perfect substitution. But in reality, this assumption will be applicable because of discrimination practices. One of which is sex discrimination or the differentiation between men and women (Bellante \& Jackson, 1990: 273-274).

Indeed, the income gap between men and women or gender wage gap is one of the indicators of women's disadvantaged position in the labor market. Data show that in almost all countries and types of economy in the world women have an average income of twothirds of men's income, according to United Nation in 1999.

Although there has been a lot of empirical literature on the issue of discrimination, there is no size consensus as to what is the best thing to do for the influence of discrimination (sex) in the labor market. It is difficult to find the conclusion that current labor market discrimination is not the only cause of less than one ratio of women/men (Bellante \& Jackson, 1990: 284-285).

The quantitative approach for such cases is shown by an index of dissimilarity in the type or kind of work between men and women. The index of dissimilarity refers to the calculation of whether the proportion of female workers in one type of work is balanced or appropriate (similarity) or inappropriate (unsimilarity). The purpose of calculating this index itself is to see whether the percentage of men and women workers is spread evenly across all types of work. The lower index shows that the comparison between men and women workers in one type of work is in an increasingly balanced condition (Tjiptoherijanto, 1996: 121).

In this situation, it is understandable why women's task is often invisible because according to our society (although not all societies) the involvement of women is often doing work that does not bring income or is not done outside the home (even though it brings income). Although it sounds quite rude, an opinion of an economist named A.C. Pigou stated that this situation is quite businesslike. "If all men marry their housemaids, the indicator (statistics) will show a decline in women's participation in the workforce and a reduction in national income. Because, as housewives, they will not be re-registered as wage earner and they will not be taken into account in national statistics. They become "invisible women". They are not considered as working people or earner and they will be considered as unproductive. This is precisely caused by the household work which is not paid work, thus it is not recognized as a job." (Hong, 1984: 6).

In the literature of women's study, people often make a dichotomy between what is called productive work and reproductive work since the categorization of work. It is said that in every society there must always be productive work (producing something) for the survival of its people and there must be reproductive work (literally: replacing what has been used up or lost) for the preservation of the social system or structure concerned. This discussion began to emerge in the late seventies when feminists began to study the origins of the writings of Frieder Engels and at the same time developing them more. By using these two concepts, women and social science experts have begun to realize that work that indirectly produces something, such as childcare, service to household members, sewing or washing dishes are also part of work. The reason is that community members cannot do productive work if some basic things in their household are not done. However, reproductive work does not only concern what happens in the household but also in society, for example, activities that guarantee the preservation of existing social structures, such as life cycle ceremonies or social activities in the community. There is often confusion about the meaning and use of the concept of reproduction. Edholm et al (1977) distinguished between biological reproduction (i.e. childbirth); labor reproduction (which means socialization and childcare prepare them to become the next labor reserve); and social reproduction (the process by which the relationship between production and social structure continue to be reproduced and preserved). The nature of women's work is usually associated primarily with the first two 
forms of reproductive work (biological and labor reproductions), however, women also play an important role in the work of social reproduction, such as in the work that preserves family status or in community activities.

\section{METHODS OF RESEARCH}

The type of this research is qualitative research. Moleong (1998) defined that qualitative research is a particular tradition in social science that is fundamentally dependent on observation. Whereas according to Bogdan and Taylor (1975, in Moleong, 1998) a qualitative approach is directed at the background and the individual holistically concerning the participation of women labor in the Mungkid Village, Mungkid Subdistrict, Magelang Regency, Central Java, Indonesia.

The purpose of this research is to provide a detailed description of the background, typical characters, typical personalities from the happening case or event or individual status which from its typical personalities will be made into a general matter (Kuntjaraningrat, 1977: 57). Meanwhile, the reason for choosing a descriptive research method is based on the consideration that descriptive research can produce a careful measurement of certain social phenomena.

This research tries to analyze the women's role and their reason to work. In the context of the research that will be conducted, the researcher tries to fundamentally observe how the role of women in economic development is seen based on the proportion and productivity in the Mungkid Village, Mungkid Subdistrict, Magelang Regency, Central Java, Indonesia.

This research would be carried out in Mungkid Village, Mungkid Subdistrict, Magelang Regency, Central Java, Indonesia. The reasons for choosing this research site are: First, the level of working women in Mungkid Village, Mungkid Regency is very high. Second, in general, there should be a serious attention both from the government or business actor in developing the economy especially in Mungkid Village, Mungkid Subdistrict, Magelang Regency, Central Java, Indonesia.

Data collected in this research will be obtained using related various stages namely:

- Data from Mungkid Village, Mungkid District, Magelang Regency. And a direct interview with Village Officers, Community Leaders, female workers, and related parties in this study in Mungkid Village;

- From the documents relating to the facts of this research, namely literature from the village library or other data which support the theme research.

Data collection is carried out by conducting intensive observation, the observation is mainly focused on factors such as the condition of service facilities, the implementation of services and so on.

Interview. This method is carried out because the researcher wants to obtain clearer information in Mungkid Village through community leaders, village officials and female workers.

Utilization of Secondary Data. The secondary data includes statistics on research report, regulations and so on, this data serves to complete the analysis and strengthen the conclusions obtained.

The data collected in this research will be analyzed using descriptive analysis in accordance with the problems and answers in the field. The writing systematics is in accordance with the problems and the proportion in productivity of economic development carried out by female workers in the Mungkid Village, Magelang Regency.

\section{DISCUSSION OF RESULTS}

Recently, the importance of economic resources has received more attention and has been seriously highlighted from various parties, both from the public sector and the private sector. Various seminars, training, and courses, workshops, and the like, all emphasize economic resources. All parties seem to realize the importance of economic resources for the society. 
The importance of economic resources can be highlighted from various perspectives, for example, highlighting the relevance and importance of human resources from four perspectives, namely politics, economics, technology, and socio-culture. According to Siagian (2000: 7), who further explained six perspectives or approaches in explaining the relevance and importance of economic resources. The six perspectives are political, economic, legal, socio-cultural, administrative and technological.

The importance of economic resources from this perspective leads more to the macro angle. However, it is assumed that in the end, the macro impact will also have a macro impact which will eventually touch the micro angle of human resources. In this perspective, the relevance and importance of economic resources is an important asset owned by a country up to the village. Economic resources are very positively influential for the success and progress of the region.

General opinion on the importance of the role of economic resources in the survival of every organization is clearly undeniable, and it does not reflect the importance of other determining factors. Hence, the statement that human resources are the most dominant factor is still widely respected because an organization that wishes to guarantee its acceleration surely needs the role of quality human resources. It is continued to develop adaptively and competitively in facing changes both culturally and externally (Triputro: 2001: 15).

According to Triputro (2001: 15 ), it is necessary to make the target of increasing economic resources in facing globalization and the consequences of broad economic policy because regions in Indonesia are currently far behind the regions in some countries. Regions that are currently struggling towards independence and community empowerment desperately need reliable human resources. Especially from the regional bureaucratic apparatus which is the driving force of government organizations as well as regional instruments as community service institutions.

Relating to the possibility of resistance to efforts in changing and innovating, the restructuring steps of the regional bureaucracy are the appropriate step. Fundamentally, modern organizations including the public sector are an open system. As a consequence according to Daft (1982: 4), the organization must be able to interact and adapt to the environment and continuously make efforts to change along with the process of environmental change itself in order to keep existing. For the government, it is necessary to change the method of the organization, the structure, and the guidelines for implementing the work.

The study of economic resources within the framework of the system is organization/institution of the local government bureaucracy. This economy is very decisive because its success will greatly determine the effectiveness of other resources. In the context of changes and improvements in services, HR management will strongly support the creation of effective and efficient bureaucratic performance in the service.

In general, the study of women's war in economic development is a series of activities ranging from education and experience, employment opportunities and risks being faced. Basically, in reviewing the problems of economic development in Mungkid Village cannot be separated from opportunity, chance, and family economic limitation. For example, the level of women's participation in labor, employment opportunity and the difference in wages those women must receive. These differences arise based on the empirical experience faced by women in the world of labor in all aspects of work.

Similarly, in Mungkid Village, Mungkid Regency shows that women's participation in economic development is very high as the comparison between employment rates and female population aged 20 years and over. Changes in the structure of the economy in a development process usually have a large influence on the level of women's participation in economic development. The rapid participation of women in economic development can help increase the economy and income. This will also increase opportunities for families in the form of education and daily needs.

Furthermore, the economic development process also increases family income, thereby reducing the economic pressure that forces women to work. This causes the female 
workforce to increase which result in higher female labor force participation rates. However, high economic development and the desire to enjoy the luxury of living as a result of working hard have encouraged women to re-enter the workforce and will increase the female labor force participation rate again. According to one of the women who work in the agricultural sector, she said:

"Yes, ma'am. I'm unskilled labor and I work to fulfill the family needs and other basic needs. In Mungkid Village, there are many women who work as laborer, servant, hired labor, and other services. Averagely, they work on agricultural and other services. The income can be used to fulfill the family needs and others" (Interview on December 25, 2007).

Whereas according to one of the other female workers as follows:

"My reason is not merely economic or family needs but I also want to seek other activities. I feel stuck if I keep staying at home doing nothing. While my kid is already a grown up, after finishing school and now working. This is also one of my ways to help my husband. By doing this, we can have double income. Here, almost 60 percent are working women. There are advantage and disadvantage of it. The advantage is increasing the income. One of the disadvantages is family conflict regarding the working woman. In my opinion, the family is important. If the husband does not allow me to work then I better not work" (Interview December 25, 2007). follows:

On the other hand, as the backbone of the family according to one of the workers as

"For us, working is important because I no longer have a husband. I have to feed my three sons. It is not even enough to fulfill our family's basic needs. Because I am all alone" (Interview December 25, 2007).

Furthermore, in reality, there is a problem of the opportunity for economic development for women in Mungkid Village in which there are differences between women and men, especially in terms of obtaining opportunities to improve economic business. This can arise due to stereotypes in the community regarding the role of women. Some of the obstacles for women who want to be more successful are external and internal barriers. External barrier arises because of the influence of feminism. Hence, the type of work that should be carried out is a manifestation of the stereotype of women. The external barrier can also arise due to the discrimination and lack of government funding in providing education, where women are usually the last choice in getting an education. Meanwhile, the internal barrier is caused by Horner effect, Cinderella complex, and low academic confidence. Horner effect is a condition where women having fear of success syndrome when facing a competition with men. It can cause women to achieve far below their real capability. While the Cinderella complex is the nature of dependence on protection and care.

This is in accordance with one of the Chairmen of the Family Welfare Program (PKK) in Mungkid Village as follows:

"It is true that there are some obstacles for women who work both from inside or outside. From the internal part is about families such as family needs issue, the relationship with child and husband. Meanwhile, from the external part can be other things such as not allowing women to work. However, this kind of issues can be discussed with the family members. Thus, it can be settled for the best. It is now not an era where women should just sitting around in the house while the men work. Yes, I think it is still good to work" (Interview December 25, 2007).

Table 1 - Number of women's role in economic development in Mungkid Village, Mungkid Subdistrict

\begin{tabular}{|c|c|c|}
\hline No. & Description & Total \\
\hline 1. & Agriculture & 170 people \\
\hline 2. & Industry & 60 people \\
\hline 3. & Trading & 100 people \\
\hline 4. & Services and craftsmanship & 60 people \\
\hline 5. & Housemaid & 10 people \\
\hline
\end{tabular}

Data Source: Mungkid Village Monograph 2017 
In reality, Mungkid Village shows that the economic development carried out by women is increasingly spread both in the villages and in the city. The average economic development for women in Mungkid Village comes from agriculture and trade. The seriousness of women in developing the economy in Mungkid Village is due to limited income and many demands. Data in Mungkid Village shows the increasing number of participants in economic development from year to year shown in the following data.

Based on the above table, it shows quite a large number of working women in Mungkid Village. This is driven by an advanced mindset and efforts to improve family economic development. The data shows that there are 170 people in agriculture, 60 in industry, 100 people in the trade, 60 people in craftsmanship and 10 people in housemaid. Based on this data, most female workers are in agriculture.

The opportunity for developing the village economy will indirectly provide motivation for women and men to be active in their work. The process can be expressed as a growing family economy that families will be able to meet macro and micro needs.

The effort of the role of women in Mungkid Village in carrying out economic development is actually also a record for the government and private institution. With a synergic collaboration between the government and the private sector, economic development will be more advanced and developing. In this case, it can be done by the Regional Government of Magelang Regency to the Mungkid Village Government to build synergy in economic development through mandatory business programs and work safety rules. Hence, there will be more progressive workers and new businesses will.

According to the data from the research results, economic development carried out by women in Mungkid Village, in general, is very helpful and it has helped in fulfilling the family needs both for education and daily needs. This can be seen in the following table.

Table 2 - Results of Women's Economic Development in Mungkid Village Mungkid Subdistrict

\begin{tabular}{|c|c|c|}
\hline No. & Description & Total \\
\hline 1. & Household & Monthly average of 400,000 \\
\hline 2. & Education & Monthly average of 100,000 \\
\hline 3. & Home improvement & Monthly average of 100,000 \\
\hline 4. & Others & Monthly average of 100,000 \\
\hline
\end{tabular}

Data Source: Mungkid Village Monograph 2017.

The above data shows that economic development carried out by working women in Mungkid Village for monthly household needs amounted to Rp. 400,000, for education, amounted to Rp. 100,000, for home improvement, amounted to Rp. 100,000 and others amounted to Rp. 100,000 .

The participation of women in the labor should be supported by both family and regional institution. In which it is done not only for the interest of the institution but how the community can fulfill its budget of women economic empowerment in the region. If they are going to promote and support women's productivity, there should be a special budget for developing economic opportunities for women in the regions. In this case, the active role of the community in the development process and budgeting for women's economic empowerment must be carried out to support the economic progress of the family which will affect the progress of the region.

Based on the above description, it can be understood that economic development for women in Mungkid Village in general shows increasingly good development. One of the successes of economic development is that it can be used for family, education, and productivity needs. Hence, economic development can be developed more advanced in collaboration between the business field and the government.

\section{CONCLUSION}

Economic development carried out by women in Mungkid Village can provide solutions for short and long-term needs. The role of women in business development also motivates 
the family in long term. Several things can be seen in economic development: First, it can motivate the family and the surrounding environment. Second, it can fulfill the educational needs. Third, it can fulfill the household needs including home improvement. Fourth, it can be seen as one of the forms of new change in gender equality as a form of mutual justice. The role of women in economic development needs to be regulated in law to guarantee incentives and employment. The law that regulates the existence of female workers should also regulate the received salary which is based on the regional's minimum standard of wage.

In the economic development of women, it is quite obvious that women are more diligent and careful in carrying out a task. This factor can also be seen from how they manage family needs and other needs. Hence, the economic development will be a family program managed by the village government up to the city government. The absence of rules for women in the business world will hinder the progress of the village economy. It can be guaranteed that economic development will be more advanced if the government can do this well. In order to support economic development at the village level, it requires support from the family, the village government up to the city government and private institutions. Thus, the role of women in developing the economy will be a joint program and it will not be foreign anymore.

\section{REFERENCES}

1. Bellante, D. \& Jackson, M. 1990. Ekonomi Ketenagakerjaan. Jakarta: Lembaga Penerbit Universitas Indonesia.

2. Bogdan, R. \& Taylor, S.J. 1975, Introduction to Qualitative Research Method Phenomenological Approach to the Social Sciences.New York: John Wiley \& Sons.

3. Daft, R.L. 1983, Learning the Craft of Organizational Research. The Academy of Management Review, Vol. 8, No. 4. (Oct., 1983), pp. 539-546.

4. Edholm, F., Harris, O., Young, K. 1978, Conceptualising Women, First Published January 1, 1978. Retrieved from https://doi.org/10.1177/0308275X7800300905 on October 2018.

5. Hong, E. 1984, Tenaga Kerja di Negara-negara berkembang. Universitas Indonesia, Jakarta.

6. Kuntjaraningrat, 1977, Metode-metode Penelitian Masyarakat, PT.Gramedia Jakarta.

7. Moleong, L.J 1998, Metodologi Penelitian Kualitatif. Bandung: CV. Remaja Rosdakarya.

8. Frazier Moore, 1988, Pekerja dan Produksi, Translated by Yayasan Obor Indonesia. Jakarta.

9. Siagian, S.P. (2000), Pengembangan dan Pembangunan. Bandung: Rosda Karya.

10. Siswanto, 2017, Dilema Tenaga Kerja Wanita. Jakarta: Titian IImu.

11. Tjiptoherijanto. 1996, Wanita dan Pembangunan. Yogyakarya: Pustaka Pelajar.

12. Triputro, R.W. (2014). Kepemimpinan Walikota dalam Reformasi Birokrasi Pemerintahan Daerah. Studi Kasus tentang Pola Kepemimpinan Walikota Herry Zudianto dalam Reformasi Birokrasi Pemerintahan Kota Yogyakarta. Unpublished Dissertation. Faculty of Social and Political Sciences, Universitas Gadjah Mada. 